\title{
Karadeniz Havzası Jeopolitiğinde Güç Mücadelesinin Arka Planı ve Bölgesel Güvenliğin Uluslararası Önemi
}

\author{
Nadire Filiz İRGE*
}

\section{Öz}

Avrupa, Kafkasya ve Orta Asya arasında bir geçiş güzergâhı olan ve Soğuk Savaş sonrası en fazla jeopolitik değişime uğrayan Karadeniz Havzası’nda, küresel güçlerin önceliklerinin ve bölgesel aktörlerin beklentilerinin de değişmesiyle birlikte, rekabet ve hâkimiyet mücadelesi çok yönlü bir boyut kazanmıştır. Bölgenin risk taşıyan özellikleri ile birlikte güvenlik algısı da değişerek çok daha kapsamlı bir hale gelmiştir. Bölge ülkeleri kendi çıkarları ve Karadeniz Havzası’nın güvenliği bakımından, birbirlerine karşı tehdit algılamalarını değiştirerek kapsamlı işbirliği girişimleri gerçekleştirmişlerdir. Ancak bölge ülkeleri ABD ve NATO yoluyla kendilerini güvenlikli bölge, AB'ye girerek de ekonomik sorunlarını çözmeyi hedefledikleri için, kendi aralarındaki işbirliği süreçleri de zayıf kalmaktadır. Karadeniz Havzası güvenliğini içeren bir diğer önemli konu da Soğuk Savaş sonrası TürkiyeRusya Federasyonu ilişkilerinde görülen yumuşama ve işbirliği çalışmalarıdır. Montreux Boğazlar Sözleşmesi'ne göre Karadeniz, kıyıdaş ya da sınırdaş olmayan küresel güçlerin savaş gemilerini sokamadığı tek denizdir. Türkiye-Rusya, Boğazlardan geçiş ve Karadeniz’de askeri güç bulundurmak konusunda aynı görüşü paylaşmışlardır. Fakat $\mathrm{ABD}$ ve $\mathrm{AB}$, Karadeniz’de deniz gücü bulundurmayı engelleyen Montreux’nün değiştirilmesini istemektedirler. Türkiye ile Rusya arasında küreselleşme ile gelişen ekonomik ilişkilerde enerji konusunun ön plana çıkması gibi, Karadeniz'in güvenliği konusunda da, iki ülke arasında ittifakın öne çıktığı görülmektedir. Avrasya’nın merkezinde yer alan Karadeniz bölgesinde ABD özellikle son yıllardaki girişimleri ile bir etki alanı yaratmaya çalışmaktadır. Kafkasya ve Balkanlar'da olduğu gibi dünyanın diğer çatışma bölgelerine de yakın mesafede bulunan bölgede, dengenin değişmesi durumunda, Karadeniz’de olduğu kadar Kafkasya ve Ortadoğu’daki süreçlerin de olumsuz etkilenebileceğini söylemek mümkündür.

Anahtar kelimeler: Karadeniz Jeopolitiği, Güvenlik Konsepti, Enerji, Türkiye, Rusya.

\section{The Background of the Power Struggle in the Black Sea and Importance of Regional}

\footnotetext{
Abstract

In the Black Sea Basin, which has a transition route between Europe, Caucasus, and Central Asia and has undergone important geopolitical changes since the Cold War's end, the struggle for competition

Yrd. Doç. Dr., Marmara Üniversitesi Siyasal Bilgiler Fakültesi, Siyaset Bilimi ve Kamu Yönetimi Bölümü, filiz.irge@marmara.edu.tr
} 
and domination has gained a multifaceted dimension, as the changes in the priorities of global forces and the expectations of regional actors. Along with the crisis-prone characteristics of the region, the security perception has also changed and become much more comprehensive and contested. Regional countries have undertaken comprehensive cooperation initiatives, changing their perception of threats against each other in terms of their interests and the security of the Black Sea Basin. However, the process of co-operation between the two countries remains weak, as the countries of the region are seeking to solve their economic problems by entering the EU and the security zone through the US and NATO. Another important issue involving the security of the Black Sea Basin is the softening and cooperation efforts seen in relations between Turkey and the Russian Federation after the Cold War. According to the Montreux Straits Convention, the Black Sea is the only sea on which coastal or nonborder global forces can not enter warships. Turkey-Russia shared the same view on the transition from the Bosphorus and possession of military power in the Black Sea. But the United States and the EU want Montreux to be replaced, which hampers naval power in the Black Sea. It seems that the alliance between the two countries has come to the forefront in terms of the security of the Black Sea as well as the issue of energy in the economic relations developing between Turkey and Russia. In the Black Sea region, which is located in the center of Eurasia, the United States is trying to create an impact area with its initiatives in recent years. It is possible to say that processes in the Caucasus and the Middle East can be adversely affected as much as in the Black Sea if the equilibrium is changed, as in the Caucasus and the Balkans, in the region close to other conflict regions of the world.

Keywords: Black Sea Geopolitcs, Security, Energy, Turkey, Russia.

\section{Giriş}

Günümüzde teknolojide yaşanan gelişmelerin yanında sermayenin uluslararası alandaki dolaşımının hızlandığı, ulus-devletlerin ekonomiye müdahale araçlarının giderek azaldığ "küreselleşen" bir dünyadan söz edilmektedir. II. Dünya Savaşı’nın sonunda Sovyetlerin askeri tehdidine karşı ABD tarafından oluşturulan "hiçbir üssü terk etmeme stratejisi", Sovyetler Birliği’nin dağılmasından sonra yerini "çekilme” veya "yeniden yapılanma” sürecine bırakmıştır. $\mathrm{Bu}$ yeni stratejiye göre ABD Güney Asya, Ortadoğu, Afrika, Latin Amerika ve Karayipler’de üsler kurmaya başladığı gibi, Soğuk Savaş döneminde Amerikan üslerinin bulunmadığı Balkanlar, Orta Asya ve Karadeniz Havzası gibi bölgelerde de yeni bir düzenlemeye gitmekte olduğu ve askeri üsler kurmaya çalıştığı bilinmektedir. Soğuk Savaş sonrası dünyadaki en büyük küresel güç olarak kalan ABD, Yeni Dünya Düzeni adı altında "Küreselleşme” politikalarının şartlarını da oluşturmaya çalışmaktadır.

Zaten Karadeniz Havzası'nda uluslararası güç odaklarının (örneğin; ABD, Rusya ve $A B$ ) günümüz dünya sistemindeki rekabet mücadelesi de, havzanın son derece önem taşıyan ekonomik ve ticari potansiyelinden kaynaklanmaktadır. Diğer taraftan havza ülkeleri de bölgesel ve küresel rekabetten yararlanarak son dönemlerde kendi aralarında ya da hükümetlerarası düzeyde işbirliği ilişkilerini güçlendirmeye çalışmaktadırlar. Dolayısıyla Karadeniz Havzası’nın uluslararası dengeler üzerinde nedenli önemli rol oynadığının da ortaya çıkması ile birlikte, havza ülkeleri arasında yakınlaşmaları, ve işbirliği projelerinin de geliştirilmeye çalışıldığ görülmektedir. Diğer 
taraftan bölgesel işbirliği konusundaki çalışmaların, sınırlı da olsa, siyasal nedenlere dayandırılan çatışmaları geri plana çekebilmesinde önemli bir yararı olacağı açıktır. Enerji, dış ticaret, ulaştırma, çevre ve güvenlik alanları Karadeniz Havzası'nda yer alan ülkelerin bölgesel işbirliği geliştirilmesi bakımından, çalışma alanları içinde yer almaktadır. Genişletilmiş Karadeniz Havzası tanımlaması aynı zamanda bölge ülkeleri açısından çok parçalılı̆̆ı da tanımlayan bir kavramdır.

Rusya’dan başlayıp Karadeniz üzerinden Türkiye’ye aktarılması planlanan, Türkiye-Rusya arasındaki ilk doğrudan doğalgaz boru hattı projesi olan Türk Akımı, iki ülke arasında yapılan anlaşma ile devlet başkanları tarafından onaylanmış (10 Ekim 2016) bulunmaktadır. 2000’li yılların başından itibaren Mavi Akım Projesi ekonomik, teknik ve stratejik boyutları ile Türkiye kamuoyunun gündemini en çok işgal eden konular arasında yer almıştır.

\section{Karadeniz’in Uluslararası Önemini Arttıran Nedenler}

Karadeniz Havzası, sahip olduğu ekonomik ve ticari potansiyelinin yanında enerji kaynakları bakımından da zengin ve Doğu-Batı yönlü enerji ulaştırma hattı üzerinde bulunmaktadır. Hazar-Orta Asya Bölgesi ile Ortadoğu’dan gelen ticaret yollarının Avrupa'ya ulaşmasını sağlayan güzergâh üzerinde konumlanmış olan Karadeniz Havzası’na ilişkin Soğuk Savaş dönemini hatırlatan bölgesel hakimiyet alanları ile güvenlik tartışmalarının gündeme gelmesi, havzanın son derece önemli bir ekonomik potansiyele sahip olmasından kaynaklanmaktadır: Ayrıca havzanın etrafında bulunan ülkelerin aralarındaki sosyo-kültürel farklılıkların da bu duruma eşlik ettiğini görmekteyiz.

Avrupa, Asya ve Afrika kıtalarının birleştiği bir coğrafi konumda yer alan Türkiye, yolların kesiştiği ve geçiş hattı ülke özelliği nedeniyle Avrupa, Kafkasya, Orta Asya, Kuzey Afrika ve Ortadoğu'yu birleştiren kara, deniz, demir ve hava yolları ile enerji taşımacılığında merkezi bir konumda bulunmaktadır. Dünyanın en önemli petrol rezervlerine sahip olan Ortadoğu ve Hazar Havzası ile önemli deniz ulaştırma yollarının kavşağındaki Akdeniz Havzası içinde yer alan Türkiye, tarihte her zaman önemini sürdürmüş olan Karadeniz Havzası ve Boğazlar, Balkanlar, etnik çatışmalar yanında zengin doğal kaynaklara sahip Kafkasya ve Orta Asyảnın oluşturduğu coğrafyanın merkezinde bulunmaktadır.

Bazın ve De Tapia tarafından “üç jeopolitik alanın kavşağında bulunan ve üniter model ile çoklu ayrışmalar arasında kalan dinamik bir uzam” olarak tanımlanan Türkiye’nin; "oynadığı siyasi rolün öneminin kabul edilmesinin yanı sıra demografik ve ekonomik ağırlığ topluluğu içinde kendisine yer edinerek uluslararası sahneye döndüğü” (Bazin \& De Tapia, 2015:11-13) dile getirilmiştir. Üç kıtanın birleştiği noktada yer alan Türkiye, jeopolitik konumu nedeniyle, uluslararası ham petrol ve doğalgaz boru hatlarının da artmasından sonra, Hazar petrol ve doğalgaz rezervlerinin Batı'daki pazarlara taşınmasında büyük rol oynayacaktır. Dolayısıyla Türkiye, bölgenin Batı ile bütünleşmesi açısından Kafkasya ve Orta Asya’yı Avrupa’ya bağlayan boru hattı projeleri olarak Doğu-Batı Enerji Koridoru Projesi’nin gerçekleştirilebilmesi üzerinde yoğun çalışmalar üstlenmiş bulunmaktadır. Bütün bunlar, bir taraftan ticaret ve ulaşım yollarını 
birleştirici özelliği ile merkez ülke, diğer taraftan ulaşım ve taşımacılık bakımından "geçiş hattı", enerji hatları bakımından da "kesişim noktası ve merkez" olması (Durgun, 2015:111) Türkiye'nin jeopolitik konumunun önemini ve uluslararası rolünü ortaya koymaktadır. Diğer taraftan tarihsel açıdan bakıldığında tüm dönemlerde daima kriz bölgelerinin ortasında yer almış, ya da kriz bölgelerine yakınlığı nedeni ile Türkiye'nin karşı karşıya olduğu tehditleri ve riskleri de gözler önüne sermektedir. Sovyetlerin dağılması ve Soğuk Savaş ortamının bitmesinden sonra, ABD’nin tek süper güç olarak sistemsel düzenleyici rolüne atfedilen politikaların da değerini yitirmesinin ardından, Rusya ve Çin başta olmak üzere ekonomik ve teknolojik açıdan gelişim gösteren ülkelerin diplomatik etkilerinin de artması ile dünya çok kutuplu bir düzene doğru evrilmiş olduğunu ifade eden yorumlar da günümüzde ağırlık kazanmıştır. İşte Karadeniz Havzası da bu tartışmaların merkezinde yer alan ve aynı zamanda bu tartışmalardan da etkilenen büyük bir bölge olarak ortaya çıkmış bulunmaktadır. Çok kutupluluk tartışmalarının odağında yer alan Karadeniz Havzası, Rusya’nın doğal etki alanı içinde olduğu gibi, ABD’nin genişleme stratejisi için de önemli olduğu ortadadır. Enerji kaynakları açısından zengin olduğu kadar çok yönlü enerji projelerinin de merkezinde bulunan Karadeniz Havzası’nın uluslararası açıdan ne denli önem taşıdığı da ortadadır.

21. yüzyılı "ayaklanmalar yüzyılı" olarak ilan eden küresel güçlerin başında yer alan ABD, dünya üzerinde çıkabilecek olan her türden çatışma, gerilim ve savaştan doğrudan çıkar sağlamaktadır. Bir dünya imparatorluğu kurmayı planladığı bu yüzyılda, yeryüzündeki bütün enerji kaynaklarını ele geçirerek, dünya ekonomisini yönetmek istemektedir. Ortadoğu, Kafkaslar, Hazar Havzası ve Karadeniz Havzası, ABD için birincil derecede önemli bölgelerdir. Yeryüzünün en zengin doğal kaynaklarına ve enerji ulaşım güzergâhına da sahip olan bu bölgeler üzerinden dünya hakimiyetini ele geçirmek ve kendi coğrafyasındaki ekonomik krizi aşmak için de silah sanayini canlandırmak istemektedir. Kuzey Afrika’nın en batısından (Fas) başlayarak Kafkaslara ve Çin sınırına kadar uzanan bölgeyi kapsayan BOP (Büyük Ortadoğu Projesi) ile de, aslında bu nedenle geliştirilmiş olan bir "Kuşatma (containement) stratejisi”ni uygulamaya yönelmiştir (İrge, 2006:14-15). Dolayısıyla bu durum, "enerjinin olduğu yerde mutlaka siyaset vardır" kuralının, dünyanın her yerinde, her dönem ve her yüzyıl için geçerli bir kural olduğu gerçeğini de ortaya koymaktadır.

Tarihin Sonu teorisini ileri süren Fukayama (1993) yeni Dünya Düzeni ve Küreselleşme sürecinde ABD’nin tek süper güç olarak dünya platformunda yer alacağını iddia etmişti. Özellikle Körfez Savaşı, ABD’nin hegemonik gücünün pekiştirilmesinde önemli bir rol oynamıştır. Ancak 11 Eylül 2001 New York'ta İkiz Kuleler ve Pentagon'a yapılan saldırıların ardından başlattığı Afganistan Savaşı’nın, ABD’nin dünyada hegemonyasını güçlendirmek ve tüm dünyaya onaylatmak konusundaki politikalarının ürünü olduğu kanısındaki görüşleri güçlendirdiğini de belirtmek gerekmektedir.

Aslında Soğuk Savaş sonrası Yeni Dünya Düzeni’nin doğmadığını ifade eden Ahmet Davutoğlu, Türkiye ile ilgili konjonktürel tanımlamaların da yeterli olmadığını dile getirmiştir. Davutoğlu Türkiye ile ilgili uluslararası ilişkiler konumunu, coğrafi ve tarihi anlamda "derin sıfatını" 
(Davutoğlu, 2004) kullanarak tanımlamıştır. "Uzun dönemde belki de en fazla etkili olacak olan şeyin, dünyada jeokültürel bir yüzleşmenin yaşanıyor olması” şeklinde ifade eden Davutoğlu (2014:136, 142 ve 187) Türkiye'nin bu jeokülterel yüzleşmenin de merkezinde bulunduğunu belirtir.

\section{Avrasya'nın Merkezinde Stratejik Bir Bölge: Karadeniz Havzası}

Jeopolitik ${ }^{1}$ ve jeokültür levhalar üzerinde sınır ülkesi olan ve aynı zamanda dünya kültürlerinin kesişme noktasında bulunan Türkiye (Özey, 2002:5-6), dünyanın en sıcak ve istikrarsız bölgeleri olan Balkan ülkeleri, Kafkas ülkeleri ve Ortadoğu ülkelerinin ortasında yer alan bir coğrafyada bulunmaktadır. Savaş çemberinin içinde bulunan Türkiye, diğer taraftan bu bölgelerle tarihi ve kültürel bağlar içindedir. Dolayısıyla bu bölgelerde önemli sayıda Türk nüfusu yaşamaktadır. Bugün için dünya coğrafyasında bulunan güç merkezleri $\mathrm{ABD}, \mathrm{AB}, \mathrm{BOT}$, Çin ve Japonyadır. Türkiye tüm bu güç odaklarının tam merkezinde yer almaktadır. İşte bu nedenle Türkiye’nin jeopolitik konumu son derece önemlidir. Aynı zamanda askeri güç olan NATO’nun da içinde yer almaktadır. Cebel-i Tarık Boğazı ile Atlas Okyanusu'na, Süveyş Kanalı ile Hint Okyanusu’na ve Kızıldeniz’e bağlantılı, üç tarafı denizlerle çevrili Türkiye deniz ulaşımında stratejik bir öneme sahiptir. Asya-Avrupa ve Afrika’nın birbirlerine yaklaştığı konumda İstanbul ve Çanakkale Boğazları yer almakta olup, bu Boğazlar, Karadeniz’e komşu ülkelerin, açık denizlere açıldığı tek su yolunu oluşturması bakımından da Türkiye’nin can damarları niteliği taşırlar.

Karadeniz Havzası, küresel güçlerin uluslararası sistem eksenli güç mücadelelerinin merkezinde yer alan Avrasya coğrafyasının bir alt bileşeni olarak Avrupa ile Asya kıtalarının birbirine en yakın olduğu coğrafi alanı niteler. Türk Boğazları aracılığıly Akdeniz’e açılan ve bu bağlamda yarı kapalı bir havza olduğunu söyleyebileceğimiz Karadeniz Havzası, sahip olduğu, sosyo-kültürel ve toplumsal çeşitlilik ile de bilinmektedir. Balkanlar, Kafkaslar, Rusya-Ukrayna ve Türkiye gibi çok farklı bölgesel bileşenleri olan Karadeniz Havzası bu yönü ile objektif ve kapsayıcı bir bölgesel kimlik tanımlayamamıştır (Tüysüzoğlu, 2013:81-82, 89). Soğuk Savaş yıllarında havzanın hegemon gücü olan Sovyetlerin dağılması ile sona eren Soğuk Savaş döneminin ardından bölgede ortaya çıkan güç boşluğunda, Karadeniz Havzası'nda bağımsız hareket etmeye başlayan, aralarında etnik ve dinsel farklılıkların da olduğu yeni devletlerin ortaya çıkması, siyasal çalkantıları ve iç savaşların patlamasına da beraberinde getirmiştir.

Soğuk Savaş döneminde Karadeniz’e kıyısı olan ülkeler üzerinden ifadesini bulan Karadeniz Havzası tanımlaması, 1992'de bölgesel işbirliğini kurgulayabilmek amacıyla KEİT² (Karadeniz

1 Sürekli değişken olan siyasetin özelliğine bağlı olarak siyasi temeller üzerine oturan jeopolitik konum, siyasi coğrafyaya göre yerinin belirlenmesidir. Jeopolitik kriterler de jeopolitik konumu belirler. Bir ülkenin etkin bir siyasi birliğe yakın veya uzaklığı ya da dahil olup olmaması da jeopolitik konumunu nitelendirmede önem taşır. Konuyla ilgili olarak Bkz; Suat İlhan; Dünya Yeniden Kuruluyor jeopolitik ve Jeokültür Tartışmaları, Ötüken Yayınları, İstanbul, 1999.

2 Karadeniz Ekonomik İşbirliği Örgütü’nün (KEİ) kuruluş düşüncesinin temelinde 1980’lerde eski Sovyetlerin gıda ve tüketim mallarına ve Türkiye’nin de enerjiye olan ihtiyacının karşılanması için bir işbirliği kurulması fikri yer alır. Romanya ve Bulgaristan’n katılması ile bölgesel bir işbirliği zemininde ilerler. Serbest ticaret bölgesi 
Ekonomik İşbirliği Teşkilatı)'e üye olan ülkelerin konumlandıkları coğrafyadan da anlaşılacağ üzere mahiyet değiştirmiştir. Güney Kafkasya, Türkiye, Ukrayna ve Balkanlar’ın ekonomik, ticari ve özellikle enerji odaklı olarak birbirlerini tanımlayan bir coğrafi konuma sahip olmaları ve her birinin Karadeniz ekseninde ortaklaşıyor olmaları, Karadeniz Havzası’nın klasik tanımının değişmesinde önemli bir rol oynamıştır. Demokratik yönetim anlayışı, serbest pazar ekonomisi, insan haklarına ve azınlıklara saygı gibi Batılı değerler olarak siyasi literatüre yerleşmiş unsurları, Karadeniz'i çevreleyen coğrafyalara aktarabilmeyi ve bu bölgeleri kendi değerlerine ve sistemsel stratejilerine eklemlemeyi arzulayan $\mathrm{AB}$ ve $\mathrm{ABD}$, Geniş Karadeniz Havzası adı verilen bir bölgesel tanımlama yaratılmasına da ön ayak olmuștur (Tüysüzoğlu, 2013:250-252). Uzun yıllar çift kutuplu sistemin gerçeklerine uygun biçimde şekillendirilmiş olan Karadeniz Havzası, iki kutuplu sistemin çöktügü Soğuk Savaş sonrası dönemin en önemli açılım noktalarından biri olmuştur: nitekim küresel ve bölgesel aktörler tarafından büyük bir önem taşıyan Karadeniz Havzası ile ilgili olarak, Soğuk Savaş’ın ardından kısa bir süre sonra “Stratejik Derinlik” anlayışı çerçevesinde ortaya konulan, Karadeniz Havzası'nın mevcut uluslararası sistem ve küresel denklemler açısından sahip olduğu önemi de içselleştirilmiş oluyordu.

Türkiye’nin bölgesel liderlik rolü ile Karadeniz’e kıyısı olmayan devletlerin savaş gemilerinin Boğazlardan geçişini engelleyen ve çift kutuplu dünya sisteminin gerçeklerine göre biçimlenmiş olan Montro Sözleşmesi’nin içeriği, 1945-1991 yılları arasında havzanın uluslararası sistemdeki rekabet ve çatışmalardan uzak kalmasını sağlamıştır. Ancak bu durum Soğuk Savaş yıllarının sona ermesiyle de son bulmuş olacaktı. Sovyetlerin ve ardından Yugoslavya’nın da dağılması ile havzada çok sayıda bağımsız devlet ortaya çıkacaktı. Böylece bu devletlerin uzun bir tarihten gelen birbirleriyle yaşadıkları etnik, kültürel, dinsel, sosyal ve siyasal sorunlar da yeniden canlanmış oldu.

26 Haziran 2012'de İstanbul'da gerçekleştirilen KEİT 20. Yıl Devlet ve Hükümet Başkanları Zirvesi de, Türkiye’nin öncülüğünde kurulan ve Karadeniz Havzası ya da Soğuk Savaş sonrası dönemde kapsamı genişletilmiş Geniş Karadeniz Havzası adını alan bölgeye ilişkin kurumsallaştırılmış en kapsayıcı ve aktif bölgesel işbirliği girişimi olan KEİT’in ${ }^{3}$ üzerinde durması gereken tehditlerin ve firsatların altının çizildiği bir toplantı olmuştur (Tüysüzoğlu, 2012). Genişletilmiş Karadeniz

oluşturma fikri ön plana çıksa da, daha sonra hedef ekonomik işbirliğine dönüşecektir. İlk toplantı Türkiye’nin ev sahipliğinde Aralık 1990'da Ankara'da yapılır ve temel prensipler üzerinde katılımcılar arasında yıllar içinde yapılan çalışmalardan sonra 25 Haziran 1992'de Türkiye’nin ev sahipliğinde Rusya Federasyonu, Romanya, Bulgaristan, Ukrayna, Moldova, Azerbaycan, Gürcistan ve Ermenistan7ın katıldığı toplantıya, Yunanistan ve Arnavutluk'ta kurucu üyeler olarak katılarak 11 ülkenin devlet ve hükümet başkanları tarafından imzalanan "İstanbul Zirvesi Bildirisi” adı altında resmen işlerlik kazanmıștır. 1999 yılında KEİ bölgesel ve ekonomik işbirliği örgütüne dönüşmüş olup, 2004'te Sırbistan'ın da katılımından sonra üye sayısı 12'ye ulaşmıştır. Bkz; Alâeddin Yalçınkaya; Kafkasya’da Siyasi Gelişmeler Etnik Düğümden Küresel Kördüğüme, s.256-282.

3 KEİ bünyesinde ticaret, ekonomi, enerji, ulaştırma, haberleşme, bilim ve teknoloji başta olmak üzere 18 çalışma grubu yardımcı organlar olarak faaliyet göstermektedir. KEİ’nin, Karadeniz Ekonomik İşbirliği Parlamenter Asamblesi (KEİPA), İş Konseyi, Ticaret ve Kalkınma Bankası, Karadeniz Etütleri Uluslararası Merkezi olmak üzere 4 bağlı kuruluşu bulunmaktadır: Türkiye'nin de bu kuruluşların yönetimlerinde temsilcileri mevcuttur. Daha etkin ve sonuç odaklı çalışması, reform sürecine gidilmesi yönünde çabaların da söz konusu olduğu KEİnin Dönem Başkanlığı 1 Ocak 2017 itibariyle Türkiye’ye geçmiş bulunmaktadır. Bkz.: www.mfa.gov.tr/karadeniz-ekonomikisbirligi-orgutu_kei_tr.mfa/ (e.t. 3.1.2017) 
Havzası'nın Türkiye’nin bölgesel liderlik hedefi ortaya koyması açısından önemli bir rol oynadığı açıktır. Ancak bölgesel tüm bu yakınlaşmanın sağlanamamış olması, "Karadenizlilik” kavramının havza ülkelerinde tam anlamıyla oluşturulamamış olması, ülkelerin arasındaki çatışma ve rekabet faktörünün işbirliğinden önce gelmesi, ekonomik işbirliğinin de gerçekleşmesi önünde engel oluşturmaktadır. Küreselleşmenin de son yıllarda hızlanmış olması, enerji kaynaklarına bağımlılı̆̆ın artması ile, enerji ve ulaştırma ağlarının konumlanacağı bölgede bulunan Karadeniz Havzası́nın küresel önemini de giderek arttırmaktadır. Bütün zorluklara rağmen Türkiye’nin havzadaki işbirliği potansiyelini kendi lehine değerlendirmek konusundaki çalışmalarına hız kazandıracağını da söylememiz mümkündür.

Karadeniz Havzası'nın günümüzde neyi ifade ettiğine ilişkin Alexander Goncharenko tarafından dile getirilen düşüncenin şöyle özetlenmiş olduğunu görüyoruz: "Klasik jeopolitik teorilere göre Karadeniz Havzası, Avrasya’da düzenin ve güvenliğin en önemli köşe taşlarından biridir. Bu bölge sahip olduğu doğal kaynaklar, enerji ve ulaşım hatları ile çok hassas bir alandır. Karadeniz Havzası kalpgah (heartland) ve kenar kuşak (rimland) teorilerinin de kesişim alanını oluşturur: bölge üzerinde sağlanacak hakimiyet; Avrasya egemenliğini de beraberinde getirecektir. Bu nedenle, Karadeniz Havzası; siyasal, askeri, finansal vb. alanlarda tüm küresel aktörlerin ilgi alanında bulunmaktadır." (Tüysüzoğlu, 2013:343-344). Bu ifadeden de Karadeniz Havzasının sahip olduğu enerji kaynakları ve ulaşım güzergâhı açısından ne denli önemli bir jeopolitik özellik taşıdığı, eko-politik açıdan da son derece önemli bir değer olduğu anlaşılmaktadır. Ancak havzanın geneli açısından bakıldığında enerji kaynakları bakımından ülkeler arasında dengeli bir dağılımdan söz edilememektedir. Bu durum geniş kapsamlı bir işbirliğini havza ülkeleri açısından gerekli kılmakla birlikte, daha önce de vurgulanmış olduğu üzere, bu ülkelerin tarihsel ve sosyo-kültürel farklılıkları karşılıklı ilişkilerinde anlaşmazlıklara yol açmakta olup, bu türden bir işbirliğinin henüz gerçekleştirebilmiş olduğunu söylemek de mümkün değildir.

\section{Karadeniz Havzası Jeopolitiğinde Güç Mücadelesi}

Uluslararası ortamdaki büyük ve köklü değişiiklikler, beraberinde dönüşüm sorunuyla birlikte yeni durumu açıklamaya, çözümlemeye çalışan yaklaşımları, arayışları getirmiştir. 1990 sonrası uluslararası sistemde yaşanan köklü değişiklikler sonucu, hemen bütün ülkelerin sahip oldukları konumları sarsılmış, yeni dönemin ekonomik, sosyal, siyasal ve güvenlikle ilgili özellikleri açısından yeni tanımlamalara ihtiyaç duyulmuştur. 1990 sonrası gelişmelerin odağında bulunan Sovyetler Birliği’nin parçalanmasından sonra Asya ve Avrupa'da ortaya çıkan yeni devletler ile uluslararası politika teorileri arayışları açısından değişik bir ortam ortaya çıkmıştır. Belirli bir istikrar kazanmakla birlikte bu olaylar, Uluslararası İlişkiler teorilerini zorladığı kadar, farklı ve zengin örneklerin, yapılaşmaların, gelişmelerin yaşandığı dünyanın bu bölgesindeki politik gelişmelerin yönünü kestirmeyi de güçleştirmektedir. 1992'den sonra ortaya çıkan devletlerin etnik durumları, ekonomik ve sosyal yapılarındaki dalgalanmalar ile sınırlarının geleceği ve istikrarı tartışılır olmuştur. Bununla beraber, yıllar içerisinde her cumhuriyet için belirli alanlarda kurumlaşmalar gerçekleşmiş, bazı iç ve dış politik konularda istikrar kazanılmaya başlanmıştır 
(Yalçınkaya, 2004:343-344). Asya ve Avrupa'nın önemli bir kesişme alanını oluşturan Kafkaslar ekonomik, siyasal ve kültürel bakımdan da olduğu kadar, asırlar boyu geçiş alanı olması ve coğrafi özellikleri nedeniyle dünyanın en zengin (karmaşık) yapıya sahip bölgelerinin başında yer almaktadır. Sovyetler sonrası kurulan birçok uluslararası örgütten biri olan Karadeniz Ekonomik İşbirliği ile yeniden işlerlik kazanan Yeni İpek Yolu Projelerinin, Hazar kaynakları için alternatif ulaşım hatlarının, "bölgesel dış politika” gerçeği ile bütün bölge ülkelerinin çıkarına olabilecek yönlerinin (Yalçınkaya, 2006:2-4) bulunmasının, günümüzün uluslararası dünya sistemi açısından ne denli önem taşıdığı ortadadır.

11 Eylül terör saldırılarından sonra, Türkiye ile ABD arasında yeni bir anlam kazanan 'stratejik ortaklık' kavramı, ABD ile bölge ülkeleri arasında değişik açılardan değerlendirilmektedir. Barış içerisinde, müreffeh ve çevrenin korunduğu bölgenin, bütün ülkelerin çıkarına olup, Kafkaslar ve Karadeniz ülkelerinin yaşanabilir bir dünya için önemi katkısı olacağı ortadadır. Aksi takdirde bölgedeki karışıklık ve istikrarsızlığın etkisinin bölgeyi aşacağı da açıktır. Karadeniz ve Kafkasya halkları ve devletlerinin kendi aralarındaki anlaşmazlıkların ve sorunların bölgesel boyutları yanında, AB, ABD gibi aktif rol sahibi bölge dışı aktörlerin uzun vadeli hesapları, sorunların çözümünü daha da zorlaştırmaktadır (Yalçınkaya, 2006:4-5). Küreselleşmenin giderek hızlandığg iki kutuplu dünya sisteminin çöktüğü Soğuk Savaş sonrası dönemin günümüz dünyasında, bölgenin enerji kaynakları ve ulaşım güzergâhına ilişkin sorunlar da bütün bunlara eklendiğinde ve bölgenin jeopolitik konumu dikkate alındığında, çözümlerin daha güç bir hale geldiği de bir gerçektir.

Güney Kafkasyadda yeni bağımsız devletlerin ortaya çıkmasından sonra, ABD, bölgenin kendi jeostratejik çıkar alanına dahil olduğunu ilan etmiş, Rusya ise Sovyetlerden kalan mirasa sahip çıkmayı, aynı zamanda Ukrayna, Kazakistan ve Beyaz Rusya'ya dikkatini yoğunlaştırmıştır. Tüm jeopolitik olanaklarını da kullanarak savunma paktları, silah satmak, yeni üsler açmak vd. dış politika araçlarından yararlanmaktadır. Dolayısıyla ABD’nin Kafkasyada "yumuşak güç", Rusya’nın ise "sert güç" politikasına ağırlık verdiği konusunda uzmanların görüş birliği içinde olduklarını söyleyebiliriz (Ruintan, 2016:13). Putin döneminin ilk zamanlarında dış politika doktrini askeri doktrin ve ulusal güvenlik bölgelerinin tamamında eski Sovyet bölgesi, Moskova’nın dış politika önceliği olarak ortaya konmuştur. Bu politikanın dayanak noktasını ise, 1993’te Yeltsin'in ilan ettiği "Yakın Çevre Doktrini” oluşturmaktadır. Ekonomik, siyasi, güvenlik ve kültürel alanlarda egemenliği hedefleyen bir yaklaşımda Azerbaycan ve Ermenistan arasındaki Dağlık Karabağ meselesi çok önemli bir yere sahiptir. Çünkü Rusya, 2000’li yılların başında geri çekilme politikasından vazgeçerek, müdahaleci bir politika yürütmeye başlamıştır. Diğer taraftan NATO ve AB ile yakın ilişkiler kuran Ukrayna’nın jeopolitik, jeoekonomik ve jeostratejik konumu Kremlin'in bölge politikaları bakımından büyük bir önem taşımaktadır (Sıłacık \& Kaya, 2016:14). Rusya’nın bu iki coğrafyaya yönelik tüm güç unsurlarını içeren politikaları, ABD ve AB’nin ekonomik ve güvenlik girişimleriyle de doğrudan ilişkili olmaktadır.

2013 yılında Ukrayna’da meydana gelen ve Rusya’nın Kırım’’ ilhakıyla sonuçlanan süreç uluslararası sistemde dengeleri değiştirmiş, ABD ile Rusya arasında küresel hakimiyet mücadelesi noktasında 
süren çatışmayı, bir kez daha gün yüzüne çıkarmıştır: ABD Kırım’da temkinli bir politika izlerken, diğer taraftan Ukrayna’nın $\mathrm{AB}$ ve Batı kampında kalmasını savunmuştur. Çünkü Ukrayna ABD’nin Rusya'yı çevrelemesi açısından önemlidir. ABD Karadeniz enerji güvenliği ve havzadaki stratejik dengeyi önemsemektedir. Kırım’ın ilhakı ABD açısından güvenlik endişesi yaratmış ve Rusya’nın Karadeniz Havzası’ndaki etki alanını genişletmiştir (Öğütçü, 2016:15). Aslında Rusya Federasyonu Putin’in iktidara gelmesinden ve izlediği politikalardan sonra Soğuk Savaş sonrası bölge coğrafyasında yitirmiş olduğu etkinliği yeniden kazanmış oluyordu. Dolayısıyla ABD, Karadeniz Havzası'nda Rusyảnın etkili bir aktör olmasını ve etkinliğini artırmasını, bölgedeki kendi çıkarları açısından tehlikeli bulmaktadır.

\section{Bölgesel Güvenliğin Uluslararası Önemi (Kapsamlı Güvenlik Kavramı Stratejisi)}

Dünya siyasal sistemi iki kutupluyken, durumları tanımlamak daha kolaydı. Bölgeler, devletlerin siyasal tercihlerine ya da iki blok çerçevesindeki yapılanmalarına göre bölümlendirilebiliyordu. İki kutuplu sistemin ortadan kalkması, genellemeler üzerinden hareket etmeyi olanaksız hale getirdi. Bu durumda; bir ülkenin ve o ülke halkının kendi dinamikleri içerisinde ele alınmasını öngören anlayış ile yeni oluşan devletler ile açığa çıkan sorun ya da dinamikleri eski bölümlendirmeler içinden değerlendiren anlayış olmak üzere; iki tür eğilimin ortaya çıktığını söylemek mümkündür. Aslında her iki anlayışın da eksik ve hatta paradoksal sonuçlar ortaya çıkardığı söylenebilir. Her toplum sahip olduğu farklı etnik, kültürel, dinsel özelliklerle farklı sosyo-ekonomik yapı ile ilişkiler kurar ve bu durum onların iç ve dış siyasetinde belirleyici olur. Bununla birlikte tarih boyunca işbirliği ya da çatışmalar biçiminde olsun, karşılıklı sürdürülen ilişkileri olur ve bu yolla aynı alt sistemin parçalarına dönüşmelerine yol açan ortak özellikler gelişir (Dedeoğlu, 2008:11-12).

Genişletilmiş Karadeniz Havzası, Bulgaristan ve Romanya yoluyla Avrupa’dan başlamakta olup, Kazakistan ve Türkmenistan yoluyla Orta Asya’ya ve İran yoluyla da Ortadoğu’ya kadar genişlemektedir. Doğal olarak, Güney Kafkasya ülkelerini ve Kuzey Kafkasya halklarını da içeriyor ya da yakından ilgilendiriyor. Bölgedeki sorunların çatışmacı gidişatları düşürüldüğünde, bölgenin patlamaya hazır olduğu rahatlıkla söylenebilir. Etnik milliyetçiliğin bazı yerlerde iktidara ortaklık talepleri, bazı yerlerde ayrı devlet kurma talepleri Ortadoğu'da olduğu gibi sınırları değiştirebilecek etkiler taşıdığı açıktır (Dedeoğlu, 2008:16). Uluslararası güvenlik alanında meydana gelen değişikliklerin simgesi olarak karşımıza çıkan, 11 Eylül 2001'de Pentagon ve Dünya Ticaret Merkezine yapılan saldırılar ise, Avrasya jeopolitiğini ve bölgedeki güçler arasındaki dengeyi bir kez daha değiştirmiş olup, Türkiye’nin bölge politikası açısından olası yeni açılımları da beraberinde getirmiştir. Türkiye’nin bu yeni açılımları kullanabilmesi ve olumlu bir etkileşime dönüştürebilmesi ise, bundan sonraki süreçte özellikle Türkiye-ABD, ABDRusya, Türkiye-ABD-Rusya ilişkilerinin genel gidişatına bağlı olarak belirlenecektir (Hatipoğlu, 2005:374). Soğuk Savaş sürecinde bağlı olduğu bloğun önceliklerine göre "sert" ve "yumuşak" gücünü kullanan Türkiye, bu yeni dönem ile birlikte "yumuşak gücünü” kendi öncelikleri doğrultusunda kullanmaya fırsat bulmuş olacaktı (Hatipoğlu, 2013:87). Bütün bunlara; Rusya’nın 
Genişletilmiş Karadeniz Havzası'ndaki etkisine, ABD’nin etkisi ile AB’nin yeni üyeleri aracılığıyla etkisi de eklendiğinde, durumun daha karmaşık bir hal alacağı da kuşkusuzdur.

Bölgesel güç olma politikası, uluslararası ilişkilerde en "bıçak sırtı" durumu ifade eder. Bu politika, aktörün bölge dediği alanın görünmez sınırlarını sürekli değiştirmesine, farklı güç dengelerini sürekli kollamasına ve üstelik elinde tuttuklarını yitirmeme yolunda faaliyet sürdürmesine neden olur. Hiçbir zaman, yakın komşularıyla aynı oranda barışçıl ilişki sürdürmesinin, sistemdeki büyük güçlerin hepsi ile eşit yakınlık ya da uzaklıkta bulunmasının olanağı bulunmamaktadır (Dedeoğlu, 2014:239-240). Ortadoğu’yu Kuzey Afrika'dan Türkmenistan’a, Karadeniz’i de Hazar’a bağlayan ve Avrupa’yı Karadeniz ile Akdeniz içine yerleştiren tüm proje ve girişimlerin ortak kesimi, büyük ölçüde enerjinin güvenliği konusudur. Yukarıda adı geçen bölgeler ve bu bölgelerin çakışma noktaları, petrol ve doğalgaz iletim yolları açısından önemli kavşaklardır. Kaynak ülkeler ile tüketen ülkeler arasındaki bağın kalıcı ve sürdürülebilir olması için, taraflar arasındaki ilişkilerin barışçıl düzenlemeler içinde gelişmesini gerekli kılar. Ayrıca, tüm enerji hatlarının geçtiği bölgelerdeki toplumsal ve ekonomik istikrarın da, sürdürülebilirlik açısından kaçınılmaz (Dedeoğlu, 2008:21) bir gereklilik olması da zorunludur.

Ticaretin, milletler arasındaki en eski ve en önemli bağ olduğundan yola çıkan Robert Gılpın, ticaretin savaşlarla birlikte, uluslararası ilişkilerin gelişmesinde merkezi bir rol oynadığını

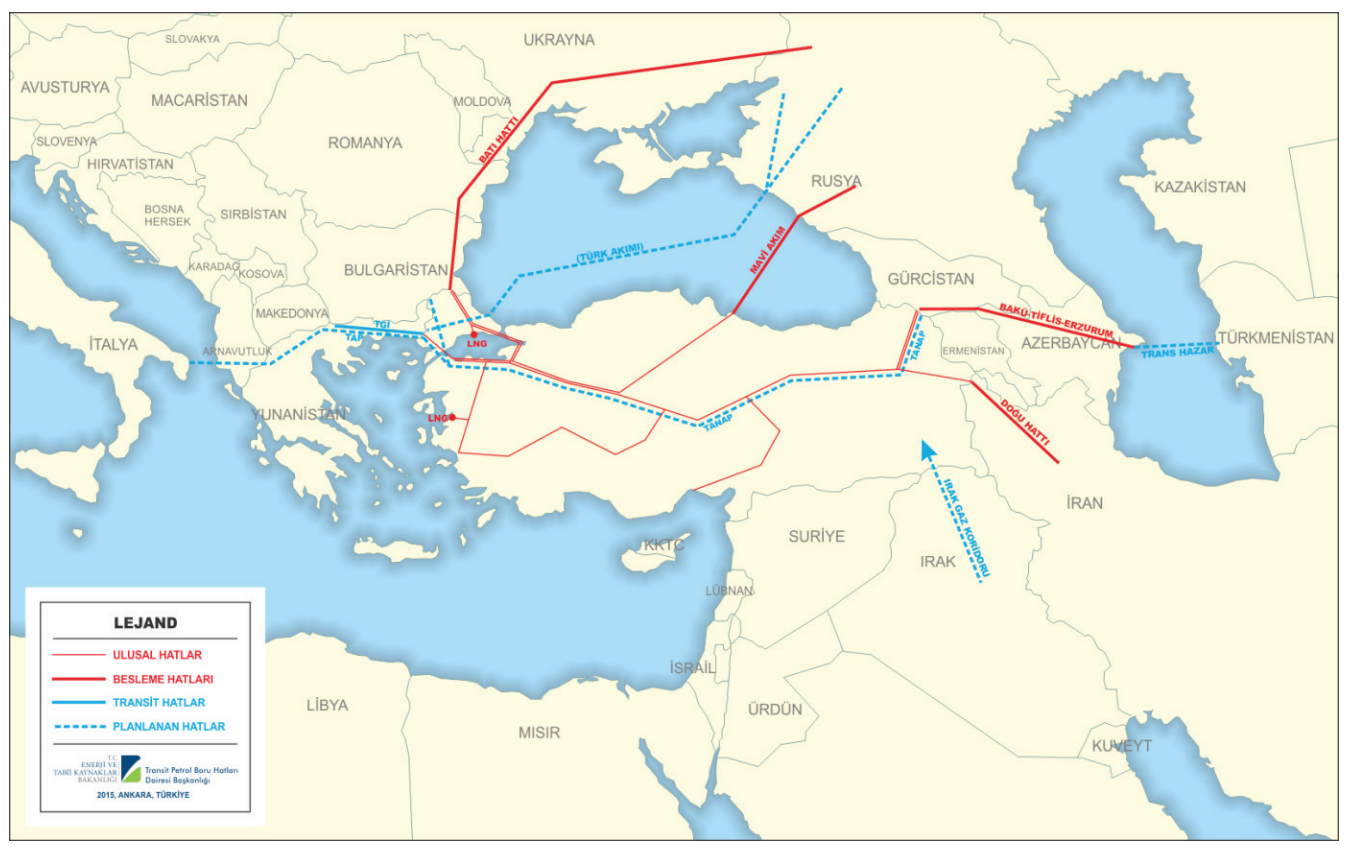

Şekil I: Uluslararası Doğal Gaz Boru hatları

Kaynak: Enerji ve Tabii Kaynaklar Bakanlığı, (http://www.enerji.gov.tr/tr-TR/Sayfalar/Uluslararasi-Boru-Hatlari-ve-Boru-Hatti-Projeleri), (e.t. 03.02.2017) 
belirtir. Günümüz karşılıklı bağımlı dünya piyasa ekonomisi, uluslararası ticaretin önemini arttırmakta ve uluslararası ekonomi politiğin doğasını derinden etkilemektedir (Gilpin, 2015, s.213, 221). Hızla küreselleşen dünyamızda, küresel ekonomi, küresel politika ve Uluslararası Politik Ekonomi açısından belki de en değişmez olgulardan biri de ekonomik krizlerdir. Küresel bir dünyada yaşamanın "bedeli” olarak, ülkelerin çeşitli konularda birbirlerine karşılıklı bağımlı olması sonucunda bir ülkede yaşanan ekonomik, siyasal ya da sosyal bir krizin diğer ülkeleri etkilemesi kaçınılmaz olmaktadır. Günümüzde ülkelerin karşılaştıkları krizlerin başında terörizm, ekonomik kriz, artan gıda ve petrol fiyatları, çevre sorunları ve mülteci meselesi gelmekte olup, bu krizlerin sadece ulusal uygulamalar ile çözülebileceğini düşünmek yanlış olacaktır (Al, 2016:7, 13 ve 26). Bu yeni tür uluslararası bağımlılık ve ulusal firmaların birleşimi, küresel boyuttaki çokuluslu şirketlerin etkinliğini de ortaya koymaktadır.

Türkiye ile Rusya arasındaki ilk doğrudan doğalgaz boru hattı olan ve 2005 yılında devreye giren Mavi Akım, daha sonra genişletme planı çerçevesinde ismi “Güney Akım” olarak değiştirilmiştir, Rusya devlet başkanı Putin, Karadeniz’in altından geçerek Samsun'dan Ceyhan'a kadar uzanan ve ayrıca Suriye, Lübnan, İsrail ve Kıbrıs’ da içeren “Mavi Akım 1” projesini 2009'da açılklamıştır. Türkiye-Rusya arasında Rusya'dan başlayıp Karadeniz üzerinden Türkiye’ye aktarılması planlanan doğalgaz boru hattı olan "Türk Akımı Projesi” adı altındaki Anlaşma, 10 Ekim 2016 tarihinde iki ülkenin devlet başkanları tarafından imzalanmış bulunmaktadır.

Türkiye’nin üretici ve tüketici ülkeler arasındaki jeostratejik konumu, Hazar ve Ortadoğu kaynaklarının dünya pazarlarına taşınması için doğal enerji köprüsü olmasına imkan sağlamaktadır. 2000'li yıllardan itibaren Türkiye, transit ülke ve ticaret merkezi olmak amacıyla küresel ölçekteki projelere katkı sağlamakta ve çok yönlü enerji politikaları ile Batı ile Doğu’yu buluşturan bölgesel aktör rolü oynamaktadır. Petrolve doğalgazın dünyanın bu bölgesindekuralları değiştirmeye yetecek olan bir role sahip olması bağlamında Türkiye, kendisinin ve bölgesinin enerji güvenliğine ilişkin çok yönlü enerji ve de doğalgazı diplomasisi de sürdürmektedir (Enerji ve Tabii Kaynaklar Bakanlı̆̆ı). Dolayısıyla Türkiye ${ }^{4}$ istikrarlı ve güvenli bir şekilde Türkiye’ye ve dünya pazarlarına ulaştırılacak projelere destek vermekte, içinde bulunduğu bölgenin de enerji güvenliğini arttırmaya yönelik adımlar atmaktadır.

\section{Sonuç}

Sovyetlerin dağılması ve Soğuk Savaş yıllarının bitmesinin ardından, iki kutuplu sistemde kapalı konumdaki Karadeniz Havzası’nda uluslararası ekonomik ve politik işbirliği fırsatları da beraber gelmiştir. Diğer taraftan, özellikle enerji kaynakları ve doğalgaz iletim (transfer) hatları bakımından Karadeniz Havzası’nın jeostratejik ve jeopolitik konumu nedeniyle, küresel güç merkezlerinin ( $\mathrm{BBD}, \mathrm{AB}$, Rusya) çıkar çatışmalarından kaynaklanan rekabet alanına dönüşmesine yol açmıştır. AB bir taraftan eski Doğu Avrupa ülkelerini birliğe katarak, coğrafi

4 Bakü-Tiflis-Ceyhan Ham Petrol Boru Hattı ile başta Azeri petrolü olmak üzere, Hazar Bölgesi’nde üretilecek petrolün güvenli, ekonomik ve çevresel açıdan uygun bir boru hattı sistemi ile Azerbaycan ve Gürcistan üzerinden Ceyhan’a taşınması ve tankerlerle dünya pazarlarına ulaştırılması amaçlanmaktadır. 
sınırlarını da Karadeniz’e doğru genişletmek ve kendi çıkarlarına uygun düşen bir Karadeniz politikası oluşturmaya başlamıştır. NATO aracılığıyla genişlemekte olan AB coğrafyasında, kendi konumunu daha da güçlendirmeyi hedefleyen ABD’nin ise Rusya’nın çıkarlarına ciddi bir tehdit oluşturacağ 1 da açıktır.

KEİ, serbest ticaret bölgesi oluşturmak amacıyla kurulmuş bir örgütlenme olmakla birlikte, günümüzde üye ülkelerin arasındaki siyasi ilişkilerde de aktif bir rol oynamaya başlamış olup, ekonomik işbirliği teşkilatı olarak, Karadeniz Havzası ülkelerinin aralarındaki işbirliği süreçlerine de katkı sağlayacak olan ekonomik bir işbirliği teşkilatına dönüşmüş durumdadır.

Asya ve Avrupa arasında uluslararası ticari hareketliliğin önemli geçiş noktalarından olan Karadeniz Havzası, enerji kaynakları ve uluslararası doğalgaz transfer güzergâhı olması açısından, günümüzde taşıdığı ekonomik ve coğrafi potansiyel ile stratejik bir coğrafi alan özelliği taşımaktadır. Küresel güç odaklarının kendi çıkarları üzerinden, Küreselleşme ve neoliberal piyasa ekonomisine uygun biçimde yapılandırılmaya çalışılan Karadeniz Havzası'ndaki AB-NATO ve ABD’nin eko-politik stratejileri, Rusya Federasyonu tarafından egemenlik alanına müdahale olarak algılanmaktadır. Kırım’ı ilhak eden ve Ukrayna üzerinden egemenlik alanını genişletmeye çalışan Rusya’nın politikaları da havzadaki rekabet ve çatışmaların zeminini kızıştırmaktadır.

Kıyısında Romanya, Bulgaristan, Gürcistan, Ukrayna, Rusya ve Türkiye’nin yer aldığı 6 ülke olmasına ve de bir iç deniz olmasına rağmen, kapladığı alana karşın, Avrupa ve Asya’daki akarsu havzalarında bulunan 21 ülkeden toplam $2.300 .000 \mathrm{~km}^{2}$ lik geniş bir bölgenin tüm etkileri de Karadeniz’e taşınmaktadır. Karadeniz Havzası ve Türk Boğazları sistemi özellikle tuna-rain-main kanalının açılması ile Baltık ve Kuzey denizleri ile birleşerek tüm dünyanın kullandığı bir su yolu haline gelmiştir. Kıyıdaki ülkelerin bir arada organize olamamaları, tüm dünyanın radyoaktif atıklarının, kimyasal ve zehirli çöplerinin Karadeniz’e dökülmesinde önemli rolü olduğu da açıkça ortadadır. Soğuk Savaş sonrası Karadeniz Havzası güvenliğini içeren diğer bir konu da, Türkiye-Rusya Federasyonu arasındaki ilişkilerde yaşanan yumuşama ve işbirliği çalışmalarıdır. Boğazlardan geçiş ve Karadeniz'de askeri güç bulundurmak bakımından Türkiye-Rusya aynı görüşü paylaşmışlardır. İki ülke arasında Karadeniz’in güvenliği konusunda da, iki ülkenin ittifak halinde olduğu görülmektedir. Ancak ABD ve AB, Karadeniz'de deniz gücü bulundurmayı engelleyen Montreux Boğazlar Sözleşmesi’nin değiştirilmesini istemektedir. Birçok ülkenin ticari ve siyasi çıkar grupları Karadeniz Havzası'nı sadece geniş bir su haznesi ve deniz trafiğinden yararlanılan bir iç deniz olarak görmektedir. Oysa "hukuksuzluğun kendisi” de başlı başına bir "güvenlik sorunu" değil midir? Soğuk Savaş sonrasında küresel güçlerin ve bölgesel aktörlerin önceliklerinin değişmesinden kaynaklanan etkilerle de, en fazla jeopolitik değişime uğramış olan Karadeniz Havzası'nda rekabet ve hakimiyet mücadelesinin çok boyutlu hale gelmesi, bölgenin risk taşıyan özelliklerini, tehdit ve güvenlik algılamalarını da değiştirmiş ve çok boyutlu, çok kapsamlı bir hal almasına yol açmış olduğu görülmektedir. 


\section{Kaynakça}

Al, A.(2016) "Ekonomik (Finansal) Krizin Kavramsal Çerçevesinin Küresel Yönetişim Açısından Değerlendirilmesi”, içinde A. Al (der), Uluslararası Politik Ekonomi Ekonomik Krizler ve Türkiye, İstanbul: BKY Yayınları, 13-36

Bazin, M. \& Tapia, S. (2015) Türkiye Coğrafyası, (Çev. Arzu Nilay Kocasu), İstanbul: İletişim Yayınları

Davutoğlu, A. (2004) Stratejik Derinlik: Türkiye’nin Uluslararası Konumu, İstanbul: Küre Yayınları

Davutoğlu, A. (2014) Küresel Bunalım 11 Eylül Konuşmaları, İstanbul: Küre Yayınları

Dedeoğlu, B. (2008) Değişen Dünyada Yeni Dengeler, İstanbul: İlgi Kültür-Sanat Yayıncılık

Dedeoğlu, B. (2014) Uluslararası Güvenlik ve Strateji, İstanbul: Yeniyüzyıl Yayınları

Durgun, S. (2015) “Okul Coğrafyasında Türkiye Anlatılarının İnşası ve Bugünü”, içinde M. Yeşiltaş, S. Durgun ve P. Bilgin, Türkiye Dünyanın Neresinde? Hayali Coğrafyalar, Çarpışan Anlatılar, 95-118

Enerji ve Tabi Kaynakları Bakanlı̆̆ı, Uluslararası Boru Hatları ve Boru Hattı Projeleri, <http://www.enerji. gov.tr/tr-TR/Sayfalar/Uluslararasi-Boru-Hatlari-ve-Boru-Hatti-Projeleri>, (e.t. 03.02.2017)

Fukuyama, F. (1993) Tarihin Sonu ve Son İnsan, (Çev. Zülfü Dicleli), İstanbul: Simavi Yayınları,

Gilpin, R. (2015) Uluslararası İlişskilerin Ekonomi Politiği, (Çev. M. Duran \& S. Oktay) Ankara: Kripto Basım Yayım Ltd. Şti.

Hatipoğlu, E. (2005) “Orta Asyadaki Son Gelişmeler ve Türkiye”, içinde G. Güngörmüş (der), Uluslararası Çatışma Alanları ve Türkiye’nin Güvenliği, İstanbul: Okumuş Adam Yayınları,

Hatipoğlu, E. \& Sağlam, Ç. (2013) Soğuk Savaş Sonrası Türk - Rus İlişkilerinde Kamu Diplomasisi Türkiye’nin Rusya'da Uyguladığı Kamu Diplomasisi, Ankara: Bizim Akademi Yayınları

İlhan, S (1999) Dünya Yeniden Kuruluyor Jeopolitik ve Jeokültür Tartışmaları, İstanbul: , Ötüken Yayınları

İrge, N. F. (2006) Sovyetler Rusya Federasyonu’na (Balkanlar-Orta Asya-Kafkaslar) Kapitalist Kuşatma, İstanbul: IQ Yayıncilik

Öğütçü, B. (2016) “Küresel Aktörler Olarak ABD ve Rusya’nın Kırım Politikası”, içinde VIII. Uludă̆ Uluslararası İlişkiler Kongresi” Küresel ve Bölgesel Sistemde Devlet ve Devletdışı Aktörler Özel Kitapçı̆̆ı, 28-29 Kasım 2016 Uludağ Üniversitesi Mete Cengiz Kültür Merkezi, Bursa: Dora Basım Yayın Ltd. Şti., 15

Özey, R. (2002) Türkiye Coğrafyası ve Jeopolitiği, İstanbul: Aktif Yayınevi

Ruintan, S. (2016) “XXI. Yüzyılda ABD ve Rusya’nın Güney Kafkasya’da Güç Politikaları: “Yumuşak Güç, "Sert Güç", içinde VIII. Uludağ Uluslararası İlişkiler Kongresi, Küresel ve Bölgesel Sistemde Devlet ve Devletdışı Aktörler Özel Kitapçı̆̆ı, 28-29 Kasım 2016, Uludağ Üniversitesi Mete Cengiz Kültür Merkezi, Bursa: Dora Basım - Yayın, 13

Sıkacık S. \& Kaya F.(2016) "Rusya Federasyonu’nun Yakın Çevre Doktrini Kapsamında Dağlık Karabağ ve Ukrayna Politikalarını Anlamak”, içinde VIII. Uludağ Uluslararası İlişkiler Kongresi Küresel ve Bölgesel Sistemde Devlet ve Devletdışı Aktörler Özel Kitapçı̆̆ı, 28-29 Kasım 2016 Uludağ Üniversitesi Mete Cengiz Kültür Merkezi, Bursa: Dora Basım Yayın Ltd. Şti., 14.

Türkiye Cumhuriyeti Dışişleri Bakanlı̆̆ı, Karadeniz Ekonomik İşbirliği Örgütü (KEİ), <http://www.mfa.gov. tr/karadeniz-ekonomik-isbirligi-orgutu-_kei_tr.mfa>, (e.t. 3.1.2017)

Tüysüzoğlu, G. (2012) Karadeniz Havzası’nın Mevcut Görünümü ve KEİT’in İstanbul Zirvesi, $<$ politikaakademisi.org/2012/06/28/karadeniz-havzasinin-mevcut-gorunumu-ve-keitin-istanbulzirvesi/> (e.t. 3.1.2017)

Tüysüzoğlu, G. (2013) “Çok Kutupluluk Tartışmaları ve Karadeniz Havzası’nın Bölgesel Görünümü (Debates on Multipalarity and the Regional Outlook of the Blacksea Basin)", içinde A. Yalçınkaya \& Ş. Yazğan (der), Siyaset; Ekonomi ve Toplum Üzerine 4. Uluslararası Mavi Karadeniz Kongresi; 
Çatışma Çözümü, İşbirliği ve demokratikleşme İçin Yerel ve Uluslararası Perspektifler, 25-26 Kasım 2013 Marmara Üniversitesi İstanbul: Gündoğan Yayınları,

Yalçınkaya, A. (2004) Yetmiş Ylllık Kriz Sovyetler Birliğinde Moskova-Türkler İlişkileri, İstanbul: Beta Basım Yayım Dağıtım A.Ş

Yalçınkaya, A. (2006) Kafkasya'da Siyasi Gelişmeler Etnik Düğümden Küresel Kördüğüme, Ankara: Lalezar Kitabevi 